\title{
Memory, embodiment, ethics: In conversation with Wentzel van Huyssteen's work on theological anthropology
}

Author:
Robert Vosloo' 1
Affiliation:
'Department of Systematic
Theology and Ecclesiology,
Faculty of Theology,
Stellenbosch University,
Stellenbosch, South Africa
Corresponding author:
Robert Vosloo,
rrvosloo@sun.ac.za
Dates:
Received: 29 Sept. 2021
Accepted: 17 Oct. 2021
Published: 30 Nov. 2021
How to cite this article:
Vosloo, R., 2021, 'Memory,
embodiment, ethics: In
conversation with Wentzel
van Huyssteen's work on
theological anthropology',
Verbum et Ecclesia $42(2)$ sode with your
a2383. https://doi.org/10.
4102/ve.v42i2.2383
smart phone or
mobile device
to read online.
Copyright:
O 2021. The Authors.
Licensee: AOSIS. This work
is licensed under the
Creative Commons
Attribution License.

This article focuses on Wentzel van Huyssteen's work on theological anthropology, attending especially to his emphasis on the temporal and narrative dimension of personal identity. In this regard, Van Huyssteen draws on the thought of Paul Ricoeur, including his view that memory is the gateway to the self. With this in mind, the first part of the article highlights some key features of Van Huyssteen's engagement the last decade or two with the question what it means to be human, namely the affirmation of interdisciplinarity, embodiment and vulnerability. The argument is put forward that Van Huyssteen's work invites and displays the need to uphold the interconnections between embodiment, memory, vulnerability, imagination and empathy. It is furthermore claimed that his constructive proposals 'in search of self' should be seen as inextricably connected with its crucial ethical and theological motivation and contours.

Intradisciplinary and/or interdisciplinary implications: This article focuses on the South African theologian Wentzel van Huyssteen's work on theological anthropology. He is internationally renowned, and this article discusses key features of his views and brings it into conversation with the work of the philosopher Paul Ricoeur and perspectives from memory studies. As such, it presents a novel engagement that can enrich systematic theological discourse.

Keywords: memory; embodiment; Wentzel van Huyssteen; Paul Ricoeur; interdisciplinarity; vulnerability; empathy; theological anthropology.

\section{Memory as Gateway to the Self?}

One of my first memories of Wentzel van Huyssteen reaches back to a research visit in 1993 to Princeton Theological Seminary for work on my doctoral dissertation on narrative theology and ethics. He and his wife, Hester, invited us to their home for an evening with friends and pizza. Their hospitality and vivaciousness made a strong impression on me, and I was especially struck by Wentzel's absolute excitement about how good the artichokes on the pizza tasted! Hereafter, I came to appreciate greatly his commitment to excellence in his work, as well as his love for New York, Wagner and life in general. But it is probably the early memory of his embodied excitement over artichokes that most vividly comes to mind for me as a metaphor of sorts of his rich humanity and the direction of his thought. I came to view his theology, by way of speaking, not as an abstract and esoteric theology about and for angels, but as an embodied theology that is also appreciative of art, artifacts and artichokes.

Mindful of my memory of some early impressions of Wentzel van Huyssteen (whilst also acknowledging the fragility of memory) and my interest at the time in the category of narrative, I would like to focus on this contribution on his more recent work on theological anthropology. In particular, I want to attend to possible convergences between his work and the claim by scholars, notably the French philosopher Paul Ricoeur that memory is the gateway to personal identity. In the editorial introduction to the volume In Search of Self (Van Huyssteen 2011b), Van Huyssteen and Wiebe acknowledge that many of the multidisciplinary discussions of the 'self' have been shaped by Ricoeur's work. They specifically call attention to Ricoeur's notion of the self as defined by time and narrative and how he links the narrative self to empathy and the relationship to the other. As they state:

For Ricoeur, the narrative dimension of human self-awareness and consciousness not only enables us to envision new projects, to evaluate motivations, to initiate viable courses of action, but also enables us to

Note: Special Collection: Festschrift for Wentzel van Huyssteen. 
deeply empathize and identify with others ... Narrative understanding thus generates a basic act of empathy whereby the self flows from itself toward the other in a free variation of imagination. The narrative imagination transforms selfregarding into a self-for-another. (eds. Van Huyssteen \& Wiebe 2011a:3-4; cf. Kearney 2004:173; Ricoeur 1992: 113-139)

Van Huyssteen and Wiebe thus highlight and underscore Ricoeur's claim that links personal identity to narrative and our imaginative capabilities. They also note how Ricoeur links memory and imagination and affirms his claim 'that memory is the "gateway to the self" and to personal identity and as there is always a narrative component to memory, our remembering always implies narrative experience' (eds. Van Huyssteen \& Wiebe 2011a:4; cf. Ricoeur \& Homans 2008:222).

In this essay, I want to build on these comments, exploring the promise that Van Huyssteen's work on theological anthropology holds in search of a 'remembering self', a self that is not disembodied and dislocated from time and history. With this in mind, the first part of the article highlights some key features of Van Huyssteen's more recent work on theological anthropology. This is followed by a discussion on how Van Huyssteen's work invites and displays the need to affirm the interconnections between embodiment, memory, vulnerability, imagination and empathy. It is argued, in addition, that his constructive proposals 'in search of self' should not be disconnected from its crucial ethical and theological impetus and contours.

\section{Key features of Van Huyssteen's work on theological anthropology}

Over the last decade or two, Van Huyssteen's work on theological anthropology has become more extensive and pronounced. The theme is of course already prominent in his published Gifford Lectures entitled Alone in the World? Human Uniqueness in Science and Theology (Van Huyssteen 2006), and a substantial corpus of articles published hereafter builds further on the perspectives introduced and explored in this award-winning book. For our purposes here, I would like to mention three features that decisively guide and mark his reflections on theological anthropology.

A first and obvious feature is the fact that Van Huyssteen's work is defined by its interdisciplinary nature. This characteristic has always been present in his work, but it is expressed with even greater clarity and sophistication as his academic career unfolded. Indicative hereof is the first chapter of Alone in the World? That situates the question of human uniqueness as an interdisciplinary problem. In his discussion, Van Huyssteen is well aware of the problems confronting the interdisciplinary conversation between Theology and Science. He acknowledges the danger that the public can place all its trust in Science, even to the point of resulting in unabashed scientism. He also points out the reductive approach on the other side of the spectrum, namely that Theology and Philosophy can be so preoccupied with survival and an inward focus on its rich textual heritages that they become uninterested in recent developments in the Sciences (Van Huyssteen 2006:8; also with reference to Changeux \& Ricoeur 2000:1). For Van Huyssteen, however, it is actually at the boundaries between disciplines that new and exciting discoveries can take place, albeit that this task requires the necessary conceptual clarity and care. As he writes:

Interdisciplinary discourse, then, is an attempt to bring together disciplines or reasoning strategies that may have widely different points of reference, different epistemological foci, and different experiential resources. This 'fitting together', however, is a complex, multileveled transversal process that takes place not within the confines of any given discipline, but within the transversal spaces between disciplines. (Van Huyssteen 2006:9)

The transversal spaces between disciplines signify for him an authentic public realm, and it is here where the public voice of theology amidst our cultural complexities can join in discussing shared problems and overlapping epistemological patterns (cf. Van Huyssteen 2006:310). Van Huyssteen's focus on interdisciplinarity is, therefore, also connected to his understanding of the public nature of theological discourse. This emphasis on interdisciplinary continues to mark his work after 2006, as even a glance at some of the titles of his published articles reveals, such as 'What Makes Us Human? The Interdisciplinary Challenge to Theological Anthropology and Christology' (Van Huyssteen 2010a), 'Interdisciplinary Theology as Public Theology' (Van Huyssteen 2011b) and 'From Empathy to Embodied Faith? Interdisciplinary Perspectives on the Evolution of Religion' (Van Huyssteen 2014b, 2017c). Not surprisingly, the already mentioned collection of essays that Van Huyssteen co-edited with Eric Wiebe, In Search of Self, has as its subtitle 'Interdisciplinary Perspectives on Personhood' (Van Huyssteen 2011b). Central to his work one thus finds the plea for a public theology with a transversal and post-foundational rationality that can enter into 'cross-contextual, cross-disciplinary conversation' (Van Huyssteen 2010a:145; cf. Loubser 2015). At the heart of Van Huyssteen's project is indeed the exploration of various 'venues for an interdisciplinary theology' (Gregersen 2015:141-159) and the accompanying quest, as Daniël Veldsman points out, to tell the story of religious awareness with interdisciplinary integrity (Veldsman 2008:222-230). It should also be observed that Van Huyssteen does not seek in his interdisciplinary approach a mere mirroring of the findings of science but also holds to "the "semantic surplus" of theology in relation to the sciences' (Van Huyssteen 2015:208).

A second feature of Van Huyssteen's work on theological anthropology relates to the notion of embodiment. For him, a post-foundational view of embodied persons implies that the locus of rationality should be embodied persons and not abstract beliefs. As he writes:

We, as rational agents, are thus always socially and contextually embedded. Moreover, it is as embodied rational agents that we perform rationally by making informed and responsible judgments in very specific personal, communal, but also disciplinary and interdisciplinary contexts. (Van Huyssteen 2006:10) 
This focus on the embodied self is again not a new concern in Van Huyssteen's academic work, going maybe as far back as his Master's thesis in philosophy at Stellenbosch University on Merleau-Ponty, which contains a section on 'the body' (Van Huyssteen 1966:97-112; cf. also Van Huyssteen 2006:276). Not surprisingly, Van Huyssteen puts forward in Alone in the World? various arguments (as part of an interdisciplinary conversation on human uniqueness) 'for moving away from abstract, esoteric notions of human uniqueness and towards revision the issues more concretely in terms of embodied personhood' (Van Huyssteen 2006:271). In a nuanced discussion of the doctrine of the imago Dei, for instance, he calls for a revision of the notion 'in ways that would not be overly abstract and exotically baroque', but:

[T]hat instead acknowledge our embodied existence, our close ties to the animal world and its uniqueness, the deep respect for hominid ancestors that came before us, while at the same time focusing on what our symbolic and cognitively fluid minds might tell us about the emergence of an embodied uniqueness, consciousness, and personhood, and the propensity for religious awareness and religious experience. (Van Huyssteen 2006:215)

A third significant and revealing feature of Van Huyssteen work on theological anthropology is the fact that he links embodiment to vulnerability. In this regard, he observes that our 'embodied existence confronts us with the realities of vulnerability, affliction and deprivation and that this vulnerability is deeply embedded in our bodily existence' (Van Huyssteen 2006:274; cf. Van Huyssteen 2010b:342, 343). For Van Huyssteen, we can only address the idea of human uniqueness if we take our own animality and embodied personhood seriously and therefore to be human is to have an embodied consciousness. In Alone in the World? Van Huyssteen elaborates upon this emphasis in conversation with the work of various scholars, including Alasdair MacIntyre's Dependent Rational Animals: Why Human Beings Need the Virtues (MacIntyre 1999). In this text, MacIntyre explores what human beings have in common with other intelligent animal species (such as dolphins). Van Huyssteen too argues that the quest for human uniqueness should not obscure the continuity and resemblances between intelligent human and non-human animals, albeit that important differences should also be accounted for (see Van Huyssteen 2006:286). Van Huyssteen also considers MacIntyre's argument how this emphasis points to our vulnerability and affliction as embodied beings, and how this implies our dependence on others, especially, but not only in childhood and old age. Affirming these insights, Van Huyssteen (2006) stated:

I believe this rich understanding of human embodiment, now broadened to include vulnerability, affliction and dependence, will provide a challenging and all-important theological link to less abstract, more nuanced notions of human uniqueness in theology. (p. 284)

And, as Van Huyssteen further notes, not only does our embodied personhood imply vulnerability, it is through our embodied identity that we can come to grips with our affliction, disability and vulnerability (Van Huyssteen 2006:287).
Much more can be said about the central place of the features of interdisciplinarity, embodiment and vulnerability in Van Huyssteen's work on theological anthropology. However, what I especially want to call attention to in the rest of this essay is how these emphases are not devoid of ethical and theological intent and implications. To flesh this out more, I would like to recall the statement of Ricoeur - that Van Huyssteen affirms (as mentioned in the Introduction) - that memory is the gateway to the self and personal identity. Although memory is not a fully developed theme in Van Huyssteen's work, there are nevertheless strong intimations that this concept is (or should be) important for his understanding of the self, especially given how he connects (drawing on Ricoeur) memory and imagination in a way that affirms the temporal dimension of selfhood. Against this backdrop, the question can be asked what one can glean from Van Huyssteen's remarks on memory and imagination within the broader framework and direction of his theological anthropology.

\section{Memory, vulnerable embodiment and empathy}

Van Huyssteen's focus on interdisciplinarity, embodiment and vulnerability holds in my view much promise for a mutually enriching encounter with work being carried out in memory studies, including attempts to reflect on an ethics and theology of memory. In line with Van Huyssteen's plea for an interdisciplinary approach for theology, one can add that philosophical and theological reflection on the ubiquitous and slippery concept of memory too should seek cross-contextual and crossdisciplinary conversations, albeit with the awareness of the different reasoning strategies of the various disciplines. In this regard, it is useful to view 'memory' as a travelling concept, as a concept that is not fixed but can travel 'between disciplines, between historical periods and between geographically dispersed academic communities' (Bal 2002:24; cf. Whitehead 2009:4).

Of special interest for engaging the concept of memory from an interdisciplinary perspective is Van Huyssteen's chapter 'The Historical Self: Memory and Religion at Çatalhöyük' in the publication Religion at Work in Neolithic Society: Vital Matters (Van Huyssteen 2014a; cf. also for a related essay Van Huyssteen 2010c). At the outset of this essay, Van Huyssteen acknowledges the privilege of academic reflection that probes religion in the light of the excavation project at Çatalhöyük (a 9000 year-old town in central Turkey), highlighting the fact that archaeology raises the problem of semantic innovation as one asks how interpretation enables us to reconfigure long-forgotten meanings of the distant past (Van Huyssteen 2014a:109). Van Huyssteen (2014a) aligns himself with Ricoeur's comment that:

$[T]$ his kind of hermeneutical venture always involves a radically interdisciplinary journey and the long route of multiple hermeneutical detours in direct dialogue with the human sciences, the natural sciences, philosophy, and theology. (p. 109; cf. Ricoeur in Kearney 2004:124) 
In his article, Van Huyssteen is especially interested in how to conceive of the embodied human self in prehistory, and it is his conviction that archeological data 'will find the key for overcoming contemporary challenges to the idea of multidimensional, holistic notions of self and personhood' and that it will be helpful 'for an understanding of the evolution of symbolic behaviour, especially religious and ritual behaviour' (Van Huyssteen 2014a:110). He considers, for instance, the conclusion that scholars draw from the archaeological evidence that people remembered where individual bodies were buried because they later retrieved the bodies with great precision. In the typical houses at Çatalhöyük, Van Huyssteen (2014a) writes, the prehistoric self was, therefore:

[S]ituated in complex webs of memories: not only would a person who moved around the house have known about who was buried there, but individuals who were buried were remembered and as such would acquire over time a very clear narrative identity. (p. 114)

Drawing further on Ian Hodder's work on burial practices, reference is made that the remembered dead selves were also partible and for Van Huyssteen (2014b) this archaeological evidence suggests that:

$[N]$ ot the atomized and highly individualized self of our own world, but rather a self that was mutable, that can be divided physically; a self that can transform; a self that can become an ancestor, or even a bird or other animal. (p. 115; cf. Hodder 2011:61)

Van Huyssteen also draws on the work of Ian Kuijt to indicate that the social construction of personal identity is most often expressed through imagery and ritual that links the living to the dead (such as the plastering and painting of human skulls as ritual heirlooms). Without going into the details of Van Huyssteen's discussion of Kuijt's work on secondary mortuary practices and how it explores the possible interweaving of social memory and ritual practice, it is revealing to observe that this research raises for him questions about Neolithic memory and commemoration. Memories are therefore understood as linked to ritual action, and commemoration is coupled with the production of shared memories within specific communities. Van Huyssteen argues that it is the repetitiveness in ritual (linked to memory and commemoration) 'that gave this historical depth to selves that were constructed in this particular space in Neolithic prehistory' (Van Huyssteen 2014:116; cf. Kuijt 2008:173). The connection between memory, historical depth and its materiality should furthermore not be seen as static because the ongoing incorporation of objects in ritual practice keeps on generating historical meaning and in this sense 'memory itself is transformed and modified through time' (Van Huyssteen 2014:116).

What I want to highlight from Van Huyssteen's discussion in his article is how it portrays an understanding of self that is linked to memory and historical depth. He also sees correspondences with Ricoeur's analysis that defines the self by time and narrative. In this regard, Van Huyssteen affirms
Ricoeur's insight that this narrative and historical dimension 'not only enables us to envision new projects, to evaluate motivations, to initiate viable courses of action but to empathize and identify deeply with others' (Van Huyssteen 2014:117). What Van Huyssteen hereby affirms, and which is in line with the remarks in the introduction to In Search of Self referred to earlier, is that a narrative understanding of self generates empathy through memory and imagination that 'ultimately liberates us from all-consuming narcissistic interest without liquidating our identity as selves' (Van Huyssteen 2014:117). In this sense, then, memory is for Ricoeur (and Van Huyssteen) the 'gateway to the self' (Van Huyssteen 2014:118; cf. Ricoeur \& Homans 2008:222).

What emerges from these insights for Van Huyssteen is that the 'historical' self is 'articulated and constructed solely through the temporal and relational dimensions of embodied human existence' (Van Huyssteen 2014:118). For Van Huyssteen (as for Ricoeur), the categories of memory, imagination, embodiment and empathy are therefore inextricably linked as vital for the understanding of self and personal identity. Hence, an adequate theological anthropology should affirm and explore theseinterconnections.

As I have already observed, Van Huyssteen linked embodiment to vulnerability in his theological anthropology. This has of course also implications for a narrative understanding of the self that highlights memory and imagination. The link between memory and vulnerability can be seen in the fact that memory - like history and archaeology - provides fragile epistemological routes to the past because these ways of accessing the past are 'distorted by selective perception, intervening circumstance and hindsight' (Lowenthal 1995:xxii). Yet, we should not only approach memory in terms of its abuses and deficiencies but also in terms of its capacities to serve as a bridge between the present and the past, because 'we have nothing better than memory to signify that something has taken place' (Ricoeur 2004:21; cf. Vosloo 2017:33-34).

One can also approach the question of the vulnerability of memory in the light of how it is connected to the reality of forgetting. Concerning this aspect, some important contributions have been made by the neurosciences, as is seen for instance in the fascinating discussion between Paul Ricoeur and Jean-Pierre Changeux on the question of memory (Changeux \& Ricoeur 2000:138-154). Changeux points out how memory distortions often occur and that illusionary memories can even 'be created in vulnerable patients, leading them to invent a false biography' (Changeux \& Ricoeur 2000:148). Ricoeur agrees but also complements this perspective by asking whether the intentionality of memory does not give us 'a sense of the depth of time' (Changeux \& Ricoeur 2000:150).

Van Huyssteen too wants to affirm the capacity of memory. He points out that humans have developed a high degree of symbolic memory and that we are probably the only species that can use our remarkable memory 'to shape our own 
identities through mental images of past, present, and future events' (Van Huyssteen 2006:268). But Van Huyssteen is also aware that given the direct association between memory and imagination 'our recollection of our pasts are liable to distortion, and by implications our personal identities are fragile' (eds. Van Huyssteen \& Wiebe 2011a:5). What the fragility of our memory and identity implies for Van Huyssteen, moreover, is also a sense of our interdependency. Through this emphasis, we again see how Van Huyssteen draws on Ricoeur to connect memory, identityand vulnerability to underwrite a vital ethical dimension to human personhood. Also, the voice of conscience is understood as 'the remembered voices of other persons coming to us from the past' (eds. Van Huyssteen \& Wiebe 2011a:5). As a self, one is thus oneself only in and through the other. In this sense, as Richard Kearney has also highlighted with reference to Ricoeur, the shortest route to the self is through the other, and 'the self only returns to itself after numerous hermeneutical detours through the embodied language of others, to find itself enlarged and enriched by the journey' (eds. Van Huyssteen \& Wiebe 2011a:6; cf. Kearney 2004:2). To this understanding of the 'hermeneutical self' is added the emphasis that the embeddedness of the self in time through memory and imagination reveals the link between the self and the future. Insofar as the personal identity relies on keeping one's word, we are bound to the future by the act of promising (Van Huyssteen 2011b:6). Again we can see how this perspective on the self concerning what can be called 'future-oriented memory' (cf. Vosloo 2018:224-225) has for Van Huyssteen an important ethical aspect.

What emerges from the given brief discussion is Van Huyssteen's conviction that an interdisciplinary approach can provide vital perspectives for an understanding of the self that links memory, imagination, embodiment, vulnerability and the future, and that this emphasis has rich ethical implications. A central ethical notion for Van Huyssteen in this regard is empathy. In drawing on the work of Majorie Hewitt Suchocki and what she calls emphatic transcendence (Suchocki 1999:40), Van Huyssteen too seeks a form of emphatic existence that does not absolutise the self or the other but affirms the enrichment of both in a dynamic way in which 'both self and the other are at the same time transformed and preserved' (Van Huyssteen \& Wiebe 2011a:9). For Van Huyssteen, empathy creates a mutuality that allows for a differentiation that honors subjectivity and otherness. The concepts of memory, imagination and empathy condition each other on this score in important ways that can transform the self. Hence Van Huyssteen and Wiebe (2011a) wrote, with reference to Suchocki:

Empathy is, therefore, the de-absolutization of the self and therefore the transcendence of the self by knowing the self as one center among many centers. Empathy requires a 'feeling-with' that mediates exactly this sense of interconnectedness. It is, however, through the transcendence of memory that one differentiates oneself from a pathological absorption in the past by allowing the past to be past. (p. 9)

This brings to mind Ricoeur's understanding of the differentiated relationship between self and other in his
Gifford lectures published as Oneself as Another (Ricoeur 1992). One can also mention in this regard Ricoeur's (1992) admittance in a footnote of the enchantment exerted on him by a passage from the end of Georges Bernanos' novel Journal d'un cure de compagne:

It is easier that one thinks to hate oneself. Grace means forgetting oneself. But if all pride were dead in us, the grace of grace would be to love oneself humbly, as one would any of the suffering members of Jesus Christ. (p. 24)

In his work on the evolution of morality Van Huyssteen has often highlighted - drawing, for instance, on the work of Maxine Sheets-Johnstone - that the embodied roots of morality indicate that empathy 'goes to the evolutionary heart of human personhood' and that our ability to empathise is 'essential in the development of moral awareness and the realisation of a fully resonant human being' (Van Huyssteen 2013:299: cf. Sheets-Johnstone 2008:193f.). The emphasis on the emergence of a deeply embodied sense of empathy is also to be understood dynamically; it is about the body in movement because in empathy 'we move in ways we are moved to move' (Van Huyssteen 2013:299). For Van Huyssteen (2013), it is exactly the revisioning of such a profoundly embodied understanding of empathy:

[T]hat will eventually become a crucial building block for understanding the evolution of morality, of notions of good and evil, and ... a responsible way of thinking about the evolution of religion. (p. 301)

Much more needs to be said on how memory, embodiment, vulnerability and intersubjectivity are interwoven, but suffice it to say that Van Huyssteen's work with its emphasis on the embodied self convincingly reminds us - along the lines of Ricoeur's thought - that memory:

[S]erves as the ultimate mediator between time and narrative, while imagination leads the way in forging an understanding of the self as oneself only in and through the other person. (Van Huyssteen \& Wiebe 2011a:5; cf. Van Huyssteen 2017b:2)

As such the search for an adequate ethics and theology of memory will benefit richly from an engagement with Van Huyssteen's interdisciplinary work. And thinking with Van Huyssteen about questions related to theological anthropology might also, in turn, invite further reflection on how an embodied view of memory and imagination relates to a theory of action and initiative in the context of concrete social and political challenges. One can also ask questions concerning the ethical and theological implications thereof that humanity, as being in the image of God, is called - as Michael Welker discusses in his 2019/2020 Gifford lectures published as In God's Image: An Anthropology of Spirit - to justice, freedom, truth and peace (Welker 2021:44-131).

\section{Theological discourse and the capacity and fragility of embodied existence}

Wentzel van Huyssteen's interdisciplinary approach to theological anthropology rethinks personhood in conversations 
with human aspects such as the evolution of cognition, imagination, music and language, sexuality, morality and the religious disposition. What is clear from his exploration is that human nature is not viewed in an esoteric and abstract way; hence his plea for:

$[A]$ return to radically embodied notions of humanness, where our sexuality and embodied moral awareness are tied directly to our embodied self-transcendence as creatures who are predisposed to religious belief. (Van Huyssteen 2017a:9)

Van Huyssteen is therefore also interested in the movement from embodied empathy to embodied faith (see Van Huyssteen 2017c). He even thinks that cognitive science provides evidence that humans have embodied propensities towards believing in some kind of God (Van Huyssteen 2017c:13). And he refers to Calvin's conviction 'that some sense of God 'is naturally inborn in all, and is fixed deep within, as it were, in the very marrow' (I.iii.1), adding: 'In the light of contemporary discussions on the evolution of religion, it certainly does not get more embodied than this!' (Van Huyssteen 2017c:13).

Although the focus of this article is not on Van Huyssteen's recent explorations in Christology, I can add that given the centrality of embodiment in Van Huyssteen's anthropology, it is also not surprising that his more recent engagement with the theme of Christology also utilises an evolutionary epistemology (Van Huyssteen 2008, 2010). And again his discussion is not devoid of ethical intent, and therefore his interest in the evolution of morality is seen as naturally close to the question of how Christology relates to ethics. He explains concerning this relationship:

For me this can be resolved only by first asking how exactly, in the case of Jesus, God's revelation can be located not just in history, but specifically in evolutionary history. The evolutionary history of our species ... should not only directly affect notions of our own embodied personhood, but also what it would mean to understand Jesus' embodied mind, and his self-awareness as defining his personhood. (Van Huyssteen 2010:151)

Thus we see that not only Van Huyssteen's work in theological anthropology but also the related explorations in Christology and Christian faith are marked by deep historicity and embodiment. And as has already been mentioned, his emphasis on embodied existence leads to his appreciation for Ricoeur's view that understands the self as defined by time, narrative, historical depth and empathy. As such, this narrative understanding of the self, that is, marked by memory and imagination, 'provides us with a philosophical bridge theory from evolutionary anthropology to interdisciplinary theology' (Van Huyssteen 2017b:1).

In his essay 'The Addressee of Religion: The Capable Human Being', Ricoeur argues that the hermeneutics of selfhood is intertwined with the idea of capacity on every level. He writes:

All the answers to the question 'who?' the central question of the problem of personal identity - lead to designating the self as the one who can; the one who can speak, who can initiate a sequence of events ..., who can pull together in a coherent or at least acceptable narrative the story of his or her life. (Ricoeur 2016:270)

But Ricoeur also observes that these abilities also correspond a type of inability and incapacity 'whose open-ended list gives content to the idea of fragility, of vulnerability' (Ricoeur 2016:271). Questions of ethics and religion, one can say, rest on a deep level on this dual reality of human capability and fragility.

This emphasis on the capability and vulnerability of the self, as a self-constituted by time and narrative through memory and imagination, is also, in my view, at the heart of Van Huyssteen's theological anthropology. And it is on this level that theological discourse, with its 'semantic surplus', can contribute with disciplinary integrity to the discussion on what it means to be human - both in terms of our distinctive particularity and our embeddedness in a broader narrative of creaturely existence.

As Van Huyssteen (2006) expresses it eloquently in the theologically rich final paragraphs of Alone in the World?:

The distinguishing characteristic of Homo sapiens is not solely a remarkable embodied brain, a stunning mental cognitive fluidity expressed in imagination, creativity, linguistic abilities, and symbolic propensities. But even more, as real-life, embodied persons of flesh and blood, Homo sapiens - we humans - are also affected by hostility, arrogance, vulnerability and dependence, ruthlessness and cunning, and therefore are inescapably caught between what we have come to call 'good and evil'. (p. 325)

Theology can therefore offer a promising key for understanding the tragic dimensions of human existence, as well as Van Huyssteen concludes, 'why religious belief has provided our distant ancestors, and us, with dimensions of hope, redemption and grace' (Van Huyssteen 2006:325).

Van Huyssteen's theological anthropology, we can conclude, is not interested in an esoteric and abstract account of what it means to be human. Rather, it is deeply historical and embodied. It takes cognisance, one can say, of archaeology and artichokes. It reckons thoroughly with human existence in all its fullness, complexity, vulnerability and symbolic propensities.

What Craig Barnes writes in his moving foreword to Human Origins and the Image of God: Essays in Honor of J. Wentzel van Huyssteen about the book's essays can therefore also be seen as an apt description of Wentzel's views on theological anthropology because it too 'help us to understand what it is about a human life that makes it unique, and therefore a fragile beauty' (eds. Lilley \& Pedersen 2017:xi).

\section{Acknowledgements Competing interests}

The author declares that he has no financial or personal relationships that may have inappropriately influenced him in writing this article. 


\section{Author's contributions}

R.V. is the sole author of this article.

\section{Ethical considerations}

This article followed all ethical standards for research without direct contact with human or animal subjects.

\section{Funding information}

This research received no specific grant from any funding agency in the public, commercial or not-for-profit sectors.

\section{Data availability}

Data sharing is not applicable to this article as no new data were created or analysed in this study.

\section{Disclaimer}

The views and opinions expressed in this article are those of the author and do not necessarily reflect the official policy or position of any affiliated agency of the author.

\section{References}

Bal, M., 2002, Travelling concepts in the humanities: A rough guide, University of Toronto Press, Toronto.

Changeux, J. \& Ricoeur, P., 2000, What makes us think? A neuroscientist and a philosopher argue about ethics, human nature, and the brain, Princeton University Press, Princeton, NJ.

Gregersen, N.H., 2015, 'J. Wentzel van Huyssteen: Exploring venues for an interdisciplinary theology', Theology Today 72(2), 141-159. https://doi. org/10.1177/0040573615581547

Hodder, I., 2011, 'An archeology of the self: The prehistory of personhood', in J.W. van Huyssteen \& E.P. Wiebe (eds.), In search of self: Interdisciplinary perpectives on personhood, pp. 50-69, Eerdmans, Grand Rapids, MI.

Kearney, R., 2004, Paul Ricoeur: The owl of Minerva, Ashgate, Aldershot.

Kuijt, I., 2008, 'The regeneration of life: Neolithic structures and symbolic remembering and forgetting',CurrentAnthropology49(3),172-178. https://doi.org/10.1086/526097

Lilley, C. \& Pedersen, D.J. (eds.), 2017, Human origins and the image of God: Essays in honor of J. Wentzel van Huyssteen, Eerdmans, Grand Rapids, MI.

Loubser, G., 2015, 'Becoming transdisciplinary theologians: Wentzel van Huyssteen, Paul Cilliers and Constantine Stanislavski', HTS Theological Studies 71(2), 1-9. https://doi.org/10.4102/hts.v71i3.2901

Lowenthal, D., 1995, The past is a foreign country, Cambridge University Press, Cambridge.

Maclntyre, A., 1999, Dependent rational animals: Why human beings need the virtues, Open Court, Chicago, IL.

Ricoeur, P., 1992, Oneself as another, University of Chicago Press, Chicago, IL.

Ricoeur, P., 2004, Memory, history, forgetting, University of Chicago Press, Chicago, IL.
Ricoeur, P., 2016, Philosophical anthropology: Writings and lectures, vol. 3, Polity Press, Cambridge.

Ricoeur, P. \& Homans, P., 2008, 'Afterword: Conversations on freud, memory, and loss', in W.B. Parsons, D. Jonte-Pace \& S.E. Henking (eds.), Mourning religion, pp. 221-238, University of Virginia Press, Charlottesville, VA.

Sheets-Johnstone, M., 2008, The roots of morality, Pennsylvania State University Press, University Park, IL.

Suchocki, M.H., 1999, The fall to violence: Original sin in relational theology, Continuum, New York, NY.

Van Huyssteen, J.W.V., 1966, 'Die probleem van die relatiwisme met besondere verwysing na die denke van Maurice Merleau-Ponty', Unpublished Masters' thesis, Stellenbosch University.

Van Huyssteen, J.W., 2006, Alone in the world? Science and theology on human uniqueness, Eerdmans, Grand Rapids, MI.

Van Huyssteen, J.W., 2010a, 'What makes us human? The interdisciplinary challenge to theological anthropology and Christology', Toronto Journal of Theology 26(2), 143-160. https://doi.org/10.3138/tjt.26.2.143

Van Huyssteen, J.W., 2010b, 'When were we persons? Why hominid evolution holds the key to embodied personhood', NZSTH 52, 329-349. https://doi.org/10.1515/ nzst.2010.021

Van Huyssteen, J.W., 2010c, 'Coding the nonvisible: Epistemic limitations and understanding symbolic behavior at Çatalhöyük', in I. Hodder (ed.), Religion in the emergence of civilization: Çatalhöyük as a case study, pp. 99-121, Cambridge University Press, New York, NY.

Van Huyssteen, J.W. \& Wiebe, E.P. (eds.), 2011a, In search of self: Interdisciplinary perspectives on personhood, Eerdmans, MI.

Van Huyssteen, J.W., 2011b, 'Interdisciplinary theology as public theology', Acta Theologica' (Suppl 14), 95-111.

Van Huyssteen, J.W., 2013, 'Should theology take evolutionary ethics seriously? A conversation with Hannah Arendt and Maxine Sheets-Johnstone', NGTT 54(3\&4), 298-308. https://doi.org/10.5952/54-0-365

Van Huyssteen, J.W., 2014a, 'The historical self: Memory and religion at Çatalhöyük', in I. Hodder (ed.), Religion at work in a Neolithic society: Vital matters, pp. 109133, Cambridge University Press, Cambridge.

Van Huyssteen, J.W., 2014b, 'From empathy to embodied faith: Interdisciplinary perspectives on the evolution of religion', in F. Watt \& L. Turner (eds.), Evolution, perspectives on the evolution of religion, in F. Watt \& L. Turner (eds.), Evolution, religion, and cognitive science:
Oxford University Press, Oxford.

Van Huyssteen, J.W., 2015, 'A response to my colleagues', Theology Today 72(2), 206-226. https://doi.org/10.1177/0040573615586283

Van Huyssteen, J.W., 2017a, 'Lecture one: Rediscovery Darwin for theology Rethinking human personhood', HTS Teologiese Studies / Theological Studies 73(3), 1-15. https://doi.org/10.4102/hts.v73i3.4485

Van Huyssteen, J.W., 2017b, 'Lecture two: The evolution of morality: The emergence of personhood', HTS Teologiese Studies / Theological Studies 73(3), 1-18. https:// doi.org/10.4102/hts.v73i3.4487

Van Huyssteen, J.W., 2017c, 'Lecture three: From empathy to embodied faith: Interdisciplinary perspectives on the evolution of religion', HTS Teologiese Studies / Theological Studies 73(3), 1-11. https://doi.org/10.4102/hts.v73i3.4488

Veldsman, D.P., 2008, 'Wentzel van Huyssteen: Telling the story of religious awareness with inter-disciplinary integrity from an evolutionary epistemological perspective', Scriptura 98, 222-230. https://doi.org/10.7833/98-0-707

Vosloo, R., 2017, Reforming memory: Essays on South African church and theological history, Sun Media, Stellenbosch.

Vosloo, R., 2018, 'Time, memory and the search for a responsible engagement with the past', in L. Charbonnier, J. Cilliers, M. Mader, C. Wepener \& B. Weyel (eds.) the part', in L. Charbonnier, J. Cilliers, M. Mader, C. Wepener \& B. Weyel (eds.), Germany, pp. 215-226, De Gruyter, Berlin.

Welker, M., 2021, In God's image: An anthropology of the spirit, Eerdmans, Grand Rapids, MI.

Whitehead, A., 2009, Memory, Routledge, London. 